\title{
回腸を利用した膀胱拡大術後に発生した腺癌
}

\author{
黒部市民病院泌尿器科 \\ 石田 武之* 小泉 久志

\section{A CASE OF ADENOCARCINOMA OF THE RECONSTRUCTED BLADDER FOLLOWING ILEOCYSTOPLASTY}

\author{
Takeyuki Ishida and Hisashi Koizumi \\ Department of Urology, Kurobe City Hospital
}

We experienced a case of adenocarcinoma occurring in the reconstructed bladder 38 years after ileocystoplasty. The patient was a 48-year-old woman, who had undergone ileocystoplasty and left nephrectomy at the age of 10 for the treatment of tuberculous contracted bladder and left renal tuberculosis. She had often suffered from right pyelonephritis following the operation. She visited our hospital for work-up of a high value of carcinoembryonic antigen (CEA). The findings of cystoscopy, cystogram and urine cytology showed a malignant tumor of the reconstructed bladder. Then, we performed total cystectomy and right ureterostomy. The histopathological examination showed that the tumor was an adenocarcinoma which developed mainly from the ileal segment of the reconstructed bladder.

Key words: ileocystoplasty, adenocarcinoma of reconstructed bladder

要旨：症例は48歳女性. C 型肝炎の経過観察中に CEA 值の上昇がみられ，腹部超音波検査にて膀胱内の 腫瘤を指摘された。既往歴では，1957年（当時10歳）に尿路結核のため左腎摘除術および萎縮膀胱に対 して回腸を利用した膀胱拡大術を受け，1990年に，膀胱拡大術に利用された余㮃回腸の切除術が施行さ れた. 経尿道的に膀胱生検を施行し，腺癌が認められ，その後遊離回腸切除を含め膀胱全摘除術および 右尿管皮膚㾞術が施行された．病理組織学的には，周囲にかなり広汎に異型上皮を伴った高分化型の腺 癌が，回腸部分を中心に認められた。術後 CEA 值は正常化している. 回腸を利用した膀胱拡大術後に悪 性腫瘍が発生した症例は，本邦では自験例が 9 例目であり，術後期間では自験例が38年間と報告例中最 も長期間であった，全症例が，原疾患が結核であり，組織型は発生部位に依らず全症例が腺癌であった。 摘出標本のマッピングを行ない, 病理組織学的に腺癌細胞周囲に異型腺細胞および腸上皮化生が確認さ れた．若干の文献的考察を加えて報告した。

キーワード：膀腅拡大術, 回腸, 腺癌

\section{緒 言}

膀胱や尿管の代用として腸管を利用し，尿路拡大術 を行なう方法は，古くより行なわれている，その後， 大腸を利用した尿路形成術後に大腸からの腺癌発生率 が高いことが知られるようになり ${ }^{1)}$, 現在では尿路形 成術は回腸が利用されることが多くなってきている. 一方，その利用された回腸に悪性腫瘍が発生した報告 は稀である.今回，我々は回腸を利用し膀胱拡大術を 施行され，その38年後に発生した膀胱内の腺癌の 1 例

*現 水見市民病院泌尿器科
を経験したので, 若干の文献的考察を加えて報告する. 症例

患者：48歳，女性.

主訴：膀胼内腫瘤の精查.

家族歴：父が肺結核

既往歴：1957年（当時10歳）に尿路結核のため左腎 摘除術および萎縮膀胱に対して回腸を利用した膀胱拡 大術を受けた。その後，年 2 回程度の右急性腎盂腎炎 を起こしていた。

1990年 5 月に残尿を減少させる目的にて, 膀胱拡大 術に利用された余剰回腸切除術が施行された。 
図 1A 1990年の膀胱造影. 萎縮した膀胱にループ状 にした回腸が吻合されている.

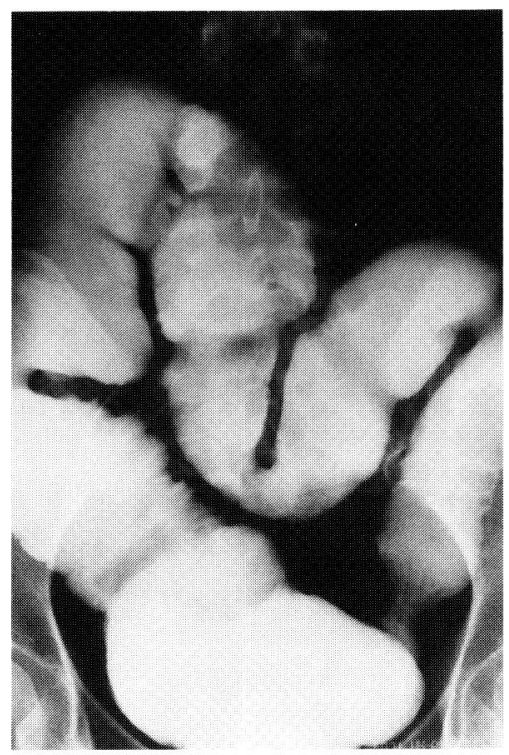

現病歴：1995年 5 月, C 型肝炎の経過観察のため年 1 回施行されていた会社での血液検査にて, CEA 值の 上昇が認められた，当院胃腸科での消化管検査では異 常は認められなかったが, 腹部超音波検査にて膀胱内 の腫瘤を指摘され当科へ紹介となった。

入院時現症：身長 $150 \mathrm{~cm}$, 体重 $44 \mathrm{~kg}$. 下腹部正中お よび左側腹部に手術痕を認めた。

入院時検査所見：血液検査にて CEA (EIA) が95ng/ $\mathrm{ml}$ (正常值6.4以下) と高值を呈し, 尿沈椬にて RBC $2 \sim 3 / \mathrm{HPT}, \mathrm{WBC} 30 \sim 40 / \mathrm{HPT}$, 尿培養にて Enterococcus Sp. $\left(10^{3} / \mathrm{ml}\right)$ と尿路感染が認められた。尿細 胞診は class V であった，膀胱鏡では，回腸部膀胱は 粘膜全体に浮腫状の変化が認められ, 萎縮膀胱との吻 合部の左後方の回腸部分に，表面が白苔状の母指頭大 の広基性腫瘤が認められた.1990年の遊離回腸切除前 の膀胱造影では（図 1A)，膀胱上部に吻合された環状 の遊離回腸が造影されているが陰影欠損像はなく，今 回の入院時の膀胱造影 (図 1B) には, 右膀胱尿管逆流 および回腸部膀胱の左上方に約 $2 \mathrm{~cm} の$ 陰影欠損が認 められた. CT, MRI では, 周囲臓器への浸潤, リンパ 節の腫張や遠隔転移の所見は認められなかった。

1995年 9 月11日, 経尿道的に TUR-Bt 抢よび非腫瘤 部の粘膜の生検を施行した. 病理組織学的には, 腫瘤 病変部のみに中等度分化型腺癌が認められたが, 深達 度は決定できなかった。
図 1B今回 (1995年) の膀胱造影。ループ状の回腸の 部分は1990年に切除されているが,上方約 $4 / 5$ は依然 として回腸による膀胱で,下方約 $1 / 5 か ゙$ 萎縮した元来 の膀胱である. 左上方に腫瘍による陰影欠損が認め られる。

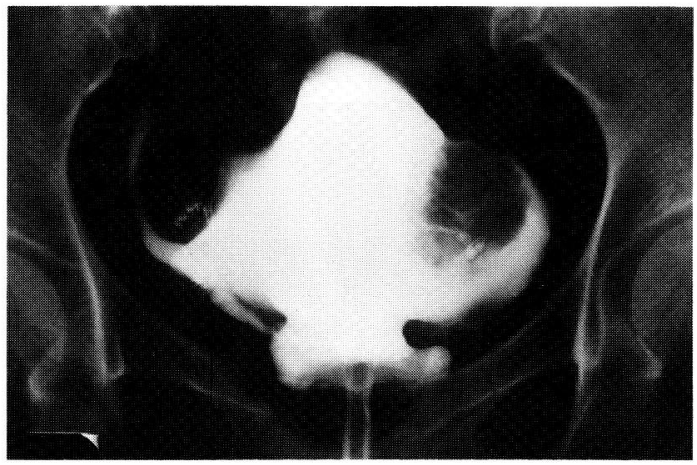

図 2 組織所見(HE 染色, 100倍). 粘液を産生する高 分化型の腺癌細胞が認められる。

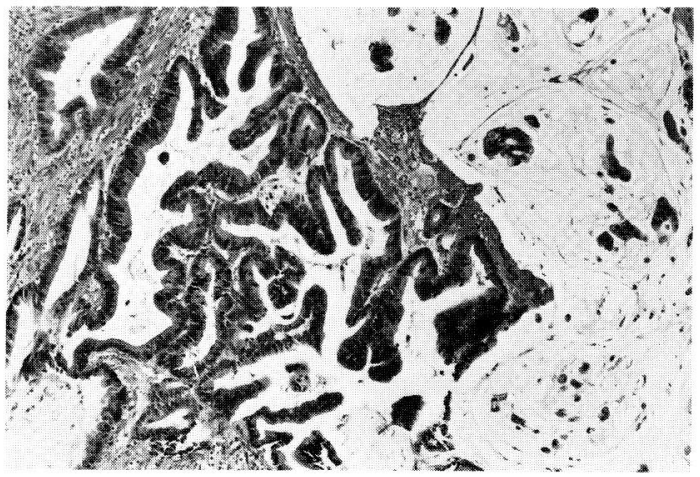

以上の検査成績より，膀胱拡大術後に発生した再建 された膀胱内の腫瘍と診断し，TUR 後の腫瘍の残存 を考え1995年10月 9 日，遊離回腸切除を含め膀胱全摘 除術および右尿管皮膚瘻術を施行した。

病理所見：粘膜内に限局する，粘液産生性高分化型 腺癌がみられた，腫瘍は本来の回腸部分を中心に広汎 に進展し，また一部では吻合部を越えて本来の膀胱の 部分にも認められた（図 2 ). 明らかな癌の周囲には, かなり広汎に異型型腺上皮を伴っていた，粘膜下層へ の浸潤は認められなかったが, 遊離回腸の腸間膜から 採取されたリンパ節の 1 個に転移が認められた。

術後 2 週間にて CEA 值は正常化した。

$$
\text { 考察 }
$$

尿管 S 状結腸吻合術後に悪性腫瘍が発生する頻度 
表 1 膀胱拡大術後に発生した悪性腫瘍 9 例（本邦全 症例)

\begin{tabular}{l|l|c}
\hline & & 自験例 \\
\hline 年齢 & $42 \sim 65$ 歳 (平均52歳) & 48 歳 \\
性別 & 男性 6 例, 女性 3 例 & 女性 \\
原疾患 & 結核(全症例) & 結核 \\
術後期間 & $14 \sim 38$ 年間(平均25年間) & 38 年間 \\
組織型 & 腺癌(全症例) & 腺癌 \\
発生部位 & 遊離回腸 3 例, 吻合部 3 例, 膀胱 3 例 & 遊離回腸 \\
\hline
\end{tabular}

が高いことは知られている゙が，回腸を利用した膀胱 抎大術後に悪性腫瘍が発生した症例は，1971年の Smith ら ${ }^{21} の$ 報告以来10数例を認めるのみである。本 邦では1983年に Takasaki らが最初の報告をして以 来自験例を含め 9 例が報告されている（表 1 ）に過ぎ ない. 本邦の全症例が, 原疾患が結核であり, 術後期 間の平均は25年間で, 自験例は 38 年間と報告例中最も 長期間であった。組織型は, 発生部位に依らず全症例 が腺癌で, 移行上皮癌の症例は報告されていなかった。 小腸は全消化管の長さの $75 \%$ 以上, 粘膜表面積の 90\%以上を占めているにもかかわらず, 腫軥発生頻度 は低率で，小腸悪性腫瘍は全消化管悪性腫湯の $2 \%$ 以 下にすぎないとされている，その理由として，以下の ような仮説が挙げられている ${ }^{4) 51}$. 1) 内容停滞時間が 短いため発癌物質に曝露される時間が短い,2）内容物 が液状であるため発癌物質の濃度が低い,3）小腸のあ る種の消化酵素が発癌に抑制的に作用する可能性があ る，4）腸内細菌叢が少ない，5）発達した免疫機構に よって種々の発癌ウイルスの感染から防御されてい る.膀胱拡大術に利用された小腸は，蓄尿という膀胱 機能の役割を待つが，栄養素の消化・吸収という働き を失い, 小腸が持つ本来の免疫機構や消化酵素分泌能 の変化が予想される。また，このような小腸内では自 験例のように残尿があり，そのために尿路感染を繰り 返しているものと思われ, 尿路内に含まれる発癌物質 に曝露される時間の長期化や細菌の常在化も考えられ る.これらのことは, 前記した小腸内の悪性腫瘍の発 生頻度が低い理由とされる仮説の条件と異なることと なり, 膀胱搥大術に利用された小腸内に悪性腫瘍が発 生するに至ったことが予想される. Shokeir ら ${ }^{6}$ は, 腸 管を利用し何らかの尿路再建術が施行され，10年以上 の経過観察が可能であった186症例について検討し，そ の内 4 例（2\%）に尿路悪性腫場の発生を認めたと報 告し, 術後 10 年以上経過した症例は少なくとも毎年の 細胞診が必要であろうと述べている.

\section{図 3 摘出標本の粘膜面のマッピング}

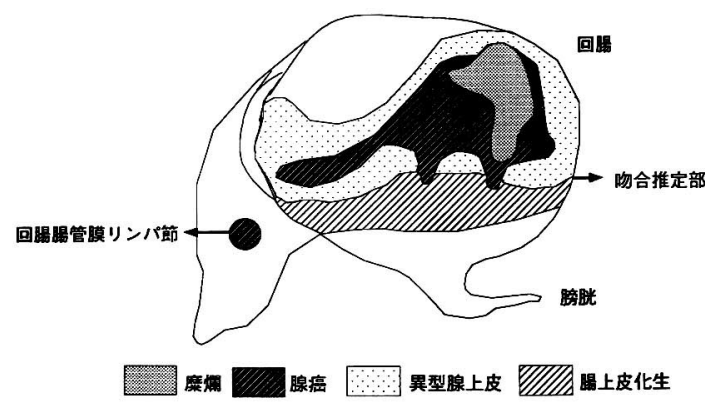

自験例の全割標本を作製し，図のようなマッピング を行なった (図 3 ). 病理組織学的に TUR-Bt 後の糜爛 部を含め, 広汎な腺癌の大部分は本来の回腸部分に存 在するが，一部では吻合部を越えて萎縮した本来の膀 胱にも認められた。また，その腺癌部分を取り囲むよ うに異型腺上皮があり, さらにその外側の本来の膀胱 粘膜には腸上皮も認められた。これらのことは, 平ら の報告するように ${ }^{77}$ 膀胱上皮が腸上皮に化生し, 腸上 皮化生から異型腺上皮を経て腺癌に到るという悪性化 の過程が推察された。本邦の報告例の内, 3 例では本 来の膀胱のみに悪性腫瘍が発生したと報告されている (表 1 ). その全症例が腺癌であったことからも，回腸 を利用した拡大術後の膀胱粘膜に腸上皮化生が起こ り, 癌化へと進行する可能性も考えられる.

免疫組織学的には, 主病巣の腺癌およびリンパ節の 転移部でも CEA 陽性を示した。本邦報告例の内, CEA 值の記載のあった 4 例中で, 術前に高值を示した例は 自験例を含め 2 例であった ${ }^{3)}$. 自験例では, 術後 CEA 値は正常化しているが，その低下の程度は手術の根治 性の評価の参考となり, 癌が残存する場合は正常值ま で低下しないことが多いとされている8 。術前にCEA 値が高值であった症例では, 臨床的な癌の再発確認の 数力月前から CEA 值が上昇傾向を示すことが多いと され, CEA 值の測定が再発転移の発見に有用との報 告 ${ }^{8)}$ がある. 自験例においても術前 CEA 值は高値であ り, 今後の経過観察において CEA 值が再発転移の重 要な指標となり得るものと思われた。

\section{結 語}

1. 回腸を利用した膀胱拡大術後38年目に発生した, 膀胱内の腺癌の 1 例を経験した.

2. 病理組織学的には, 腺癌部分を中心に異型腺上皮 と腸上皮化生が周囲に認められた。

3. 自験例に扔いては, 尿細胞診と血中 CEA 值の測 
定が診断に有用であり, 経過観察においても重要であ ると考えられた。

稿を終えるにあたり，御校閲を賜った金沢大学医学部泌 尿器科学教室, 並木幹夫教授および黑部市民病院臨床検査 科部長，原武譲二先生に深甚なる謝意を表わします。

なお, 本論文の要旨は, 第371回日本泌尿器科学会北陸地 方会に扔いて発表した。

\section{文献}

1) Leadbetter, G.W. Jr., Zickerman, P. and Pierce, E. : Ureterosigmoidostomy and carcinoma of the colon. J. Urol., 121, 732-735, 1979.

2) Smith, P. and Hardy, G.J.: Carcinoma occurring as a late complication of ileocystoplasty. Br. J. Urol., 43, 576-579, 1971.

3) Takasaki, E., Murahashi, I., Toyoda, M., Honda, M. and Waku, S. : Signetring adenocarcinoma of ileal segment following ileocystoplasty. J. Urol., 130, 562-563, 1983.

4) Lightdale, C.J. and Sherlock, P.: Tumor of the Small Bowel. Bockus' Gastroenterology, p451463, W.B. Saunders Co., Philadelphia, 1986.

5) Neugut, A. and Santos, J.: The association between cancers of the small and large bowel. Cancer Epi. Bio. Pre., 2, 551-553, 1993.

6) Shokeir, A.A., Shamaa, M., El-Mekresh, M.M., El-Baz, M. and Ghoneim, M.A.: Late malignancy in bowel segments exposed to urine without fecal stream. Urol., 46, 657-661, 1995.

7) 平紀代美, 井手ありさ, 岩本和彦, 山城勝重, 藤田 昌宏, 前野七門, 大室 博, 藤枝順一郎：回腸膀胱 形成術後 30 年で発生した膀胱腺癌の 1 例. 日臨細 胞誌，32：1046-1051， 1993.

8）染谷一彦, 辻野大二郎：CEA（carcinoembryonic antigen). 日医師会誌，102，1601-1604，1989. (1996年 5 月17日受付，10月 2 日受理) 